Research Article

\title{
Jaipong Dance: Representation of Local Culture, Popular Culture and Global Culture
}

\author{
Trianti Nugraheni ${ }^{1}$, T. Narawat ${ }^{2}$, Agus Budiman ${ }^{3}$ \\ Department of Dance Education, Indonesian Education University, J1. Dr. Setiabudi No.229, \\ Isola, Sukasari, Bandung City, West Java 40154.
}

\begin{abstract}
The dynamics of the development of Jaipongan dance in West Java have undergone several metamorphosis processes and the evolution of presentation forms as a manifestation of wise reflection on the openness of external cultural influences on the development of jaipongan dance to date. The jaipongan dance is an important part of the process of cultural inheritance in West Java, which has worldwide existence. The findings show that the form of presenting the jaipongan dance has now undergone many changes from its form and function in society. This change is a manifestation of the wise attitude of the jaipongan dance creators in seeing the potential for socio-cultural change that must be positively addressed in the jaipongan dance works they create. The color of the jaipongan dance presentation has changed, but local values are still strong.
\end{abstract}

Keywords: Jaipongan Dance, Local Culture, Popular Culture, and Global Culture

\section{Introduction}

The development of global culture in the world has influenced many local cultural products created by a supporting society (J.-B. E. M. Steenkamp \& de Jong, 2010). In this era of globalization, many local cultural developments have transformed into new forms that have the characteristics of global cultural influences. Globalization, mass culture and popular culture that are accepted by every individual in the world through various information media (J.-B. Steenkamp, 2017) the mass media are able to change the thinking style of local art actors in creating works of art products which in turn delivery to cultural products new representatives that represent and follow the spirit of global culture that is currently in demand by society.

In the last few years in Indonesia, many local cultural products were created by traditional artists who adopt global cultural ornaments to be applied in the traditional artworks they create (Asfina \& Ovilia, 2016; Hatley, 2008; Jung,2011). However, there are still many actors of local cultural arts who have not been able to understand and keep pace with the development of the globalization era which is a consequence of cultural development that must be addressed wisely in the works they create. This needs to be done as an effort to maintain and maintain the existence of local culture, some of whose products have had a relatively long developing journey in the supporting communities.

The era of globalization has influenced many local performing arts in the world, several studies were conducted, one of which was by Johnson, (2002) which examined how to play traditional music of art actors in Bali to accommodate the needs of tourism performances as a form of representation of global cultural influences. Zolberg, (2015) examines the development of contemporary art in America as a representation of the influence of global culture that has a traditional anti-aesthetic development orientation. Foley, (2001) examined how the development of Irish step dance, previously a strong local identity, was modified to find a national identity character based on a global cultural approach. Kolb, (2013) in his research describes the activities of the immigrant community in Germany and Austria in developing local folk dance as a 
national and regional identity with the concepts of nationalism, globalization and multiculturalism.

Lopes, (2014) examined the role of western museums in popularizing Chinese folk art as part of a reaction to the global cultural influences involved in its development. Aragon, (2012) even examines the efforts of ethnic groups and the Indonesian government in claiming patents for artistic and cultural wealth that have been developing for a relatively long time so that it is claimed by other countries as an impact of the free media technology in the era of globalization in popularizing various cultural arts that have developed in Indonesia. Various countries in the world including in Indonesia. However, many researchers have not shifted their attention specifically in examining the problem of the influence of global culture, popular culture on the development of traditional arts in society which will have a direct impact on the existence of local art actors. This global flows to the local (De Duve, 2007; Dimitrakaki, 2012; Roudometof, 2015)give an impact artist perpective on developing the artist work for different goals.

\section{Theoritical Framework}

The application of the concepts and theories of globalization culture also responds to the power that combines the concept of local culture and global structure (Martell, 2016; Pieterse, 2004, 2019; Rehbein, 2007). The spread of global culture to all corners of the world is no longer limited by the role of technology media (Martell, 2016; Pieterse, 2004, 2019; Rehbein, 2007) in creating forms, symbols, changing the lifestyle of an ethnic group and creating a local global culture (Livholts \& Bryant, 2017; Roudometof, 2016, 2019) as a new identity. The flow of globalization is a social process (Beck, 2018), in the globalizaton concept offers a cultural perspective that specifically discusses the social and cultural problems of a society in the perspective of contemporary world society (Appadurai, 1990; Robertson, 1992; Scholte, 2005). Changes in the cultural conception of a society in a global perspective can produce more than one form of culture that can be created by a certain ethnic community in understanding the global cultural currents that are considered more modern (Featherstone, 1990; Friedman, 1994; A. D. Smith \& Smith, 2013).

Integrating global culture into global culture is a desire to embrace various global cultural ornaments to respond to the hybridization and glocalization process (Khondker, 2004; Robertson, 1995;
M.Smith, 2007) so that culture has a new identity that has the spirit of an era culture that is considered more modern and contemporary. There have been many discussions about how a linkage and intervention between global culture and local culture becomes a conceptual unit that is able to form a modern community identity for a group of people (Featherstone, 1990; Friedman, 1994; Pieterse, 1995; Scholte, 2005; AD Smith \& Smith, 2013). Discussions about global culture often lead to something imaginary and symbolic in realizing an understanding of cultural ideology which becomes the basis for new ideas of a national cultural identity. This phenomenon is often experienced by various layers of society in the world as a consequence of global to local influence (Eriksen, 2002; Featherstone, 1990; Friedman, 1994; A. D. Smith \& Smith, 2013). The blending of global and local cultures is one of the characteristics of the assimilation process of global culture in shaping ideas, styles, identities and modernizing behavior in a social community as a form of the global gemeinschaft movement (Robertson, 1992). Within an individual can be global in one consumer domain but local in another (Robertson 1992). Although in concept, Sandikci \& Ger, (2002) described modernization for the consumer position of global cultural products, it does not always mean a form of cultural assimilation. In this position, individuals as consumers will be global but will also be local in other domains (Robertson, 1992). Within an individual can be global in one consumer domain but local in another (Robertson 1992).

In this paper, we need to provide some limitations regarding understanding the concepts and theories of pop culture as a way of thinking and acting in a social group. Tilsen \& Nylund, (2016) explain the understanding of pop culture as a consumer commodity and the practice of a certain individual or community group that has unlimited popularity in space and time among humans themselves in the context of having a culture. These consumer commodities and pop culture practices can be appreciated from various types and forms of cultural products such as: the development of art in the world, fashion trends that have become the flashlight for world culture, sports, sophisticated technological devices, and the existence of social media that influences people's behavior and lifestyle. entertainment media, as well as television technology (Jenner, 2018; Murphy, 2011; Pattie, 2013; Van Dijck \& Poell, 2015) which is one of the 
bridges in spreading the influence of pop culture on a particular individual or community group (Berger $\&$ Carroll, 2003). The industrial era in the late 1700s marked the beginning of the development of popular culture in the world (Crothers, 2017). Various art products and technology media are a sign of the power of ideas and beliefs in the influence of pop culture that are poured into various products of pop culture works (Danesi, 2008; Pieterse, 2019; Shuker, 2016).In this case Storey, (2006) explains that popular culture has become a conception (Edgar \& Sedgwick, 2007; Stokes, 2012) the way a person thinks in providing criticism and analysis of a cultural journey from time to time in a Western context.

\section{Materials And Method}

In this Entonochoriological research (Mirjana Veselinović-Hofman (ed.)., 2014), Jaipongan dance is the object of study. The material in the presentation of the Jaipongan Kreasi Baru dance is used as an object of text and context study (Narawati, 2013) which is inherent in each other. The study of texts focused on the problems of form and structure in the presentation of the Jaipongan dance. The contextual study of dance will not be separated from something that has an immanent and internal character from the problem of the sociocultural dynamics of an ethnic group that is part of the supporting community. It is different from the study of texts in dance, which can be started by studying the form and structure of the presentation of the jaipongan dance related to the problem of movement, dance accompaniment music, clothing, make-up and the stage layout used. Analysis of text data will be approached with the concept of choreography as a specific way of working in discussing dance forms and structures. Textual study will use the workings of Cultural Anthropology to examine more deeply the indications of popular culture and global culture that influence the development of current creations of jaipongan dance. Thus, the study of dance aesthetics is not only seen from the beauty of movement in the presentation of the jaipongan dance, but it is also necessary to see the existence of a social and cultural value system that builds the construction of the presentation of the jaipongan dance from the contextual side.

\section{Result And Discussion}

The Form of Jaipongan Dance Presentation in The Framework of Popular Culture
The jaipongan dance is one of the iconic products of the local culture of the people of West Java in Indonesia. Various regions in Indonesia have known the Jaipongan dance as a form of cultural identity of the people of West Java, and even have known Jaipongan dance as one of the phenomenal works of art of the Indonesian nation which has the characteristics of a global cultural heritage so that it is easily accepted by various layers of society even though they have different cultural backgrounds . This shows that the jaipongan dance that has developed in West Java is global and has a global taste so that various groups of people with different cultural backgrounds can enjoy it. In addition, the researcher considers the forms of Jaipongan dance development from the early development of the $80 \mathrm{~s}$ by the creator Gugum Gumbira until now to be able to express the national identity which is always open and adapting to every socio-cultural change of modern global society.

The development of the jaipongan dance is much inspired by the idioms of traditional art forms of the people of West Java, such as the art of ketuk tilu, bajidoran, banjet, and ibing pencak silat. Forms of movement such as, kuda kuda pasang, locat, depok, besot, bandul, kepret, sabet, tajong, jerete, peupeuh, galieur, jeblag, minced kuntul longok, minced girimis, minced mankaret, bongbang, and mincil kulawit are the forms of motion that are displayed in the traditional jaipongan dance. The forms of jaipongan dance movements are also the basis for the development of the current jaipongan dance created by young jaipongan dance creators in Indonesia.

Some young jaipongan dance creators have succeeded in changing the jaipongan dance style which has a strong character of global culture and popular culture so that it is still in demand by the millennial generation who learns jaipongan dance. The movement aesthetics developed by the creators of the current generation of jaipongan dance emphasize the combination of traditional jaipongan dance styles with the contemporary jaipongan dance styles that adopt various forms of motion outside the standard of dance movements that were created before. As a result, the development of the Jaipongan dance is divided into three groups of presentation forms that have different styles of presentation forms, namely, the traditional Jaipongan dance which was popularized by Gugum Gumbira as the initiator of the initial jaipongan dance in West Java, Indonesia, then the development of the new creation jaipongan dance and contemporary jaipongan dance 
as in the work. Acapela jaipongan dance, beatbox, and rehe mask (comedy jaipong dance).

The repertoire of creative and contemporary jaipong dances basically tries to represent the character of the current generation known as the millennial generation. The creators of contemporary and creative jaipongan dances try to wisely respond to the dynamics of today's progress through the works they create. They are trying to keep up with the times where the majority of the millennial generation today are more influenced by popular culture and global culture. That is why the jaipong dance work by this generation of creators is widely liked by the younger generation who have a strong tendency to influence global culture and popular culture. The forms of motion developed combine traditional jaipongan dance forms with creative and contemporary forms of motion that modify traditional jaipong dance forms such as attitudes and movements of sembada and keupat which are then modified into robotic imitation of Michael Jackson's legendary dancing style.

One of the contemporary jaipongan dance repertoires entitled the acapella dance which was shown on one of the private television stations in Indonesia in a talent search event featured a jaipongan dance style that exported vocal play or singing techniques where sounds such as drums, bass, and percussion were the basis for rhythm and the melody used by the dancer in bringing the movements to the acapella jaipongan dance. The acapella dance work is the same as the jaipong beatbox dance which only makes the tempo in its movements. Because the concept of the presentation of beatbox art emphasizes the imitation of percussion sounds or vocal percussion techniques which are the basis for beatbox in producing beat and rhythm sounds. The motion that is explored in the idea of this work is more to process the strength of the tempo and the dynamics of the beat and the rhythm that is generated from the human voice playing this beatbox art game.

The study of the current jaipongan dance movements is not only interesting in the development of new motion idioms developed by jaipongan dance creators in the present era. The study of the jaipongan dance movement is also centered on the study of the dancer who presents the jaipongan dance material that he is dancing. This study is related to the three aesthetic aspects of the quality of one's dances in performing a jaipong dance. Nuriawati. \& Nalan, (2018) stated that there are three aesthetic aspects of a dancer in performing the jaipong dance, namely aspects of flexibility, kewes, and pantes. The use of these local terms shows the strength of local wisdom of the Sundanese people in Indonesia which reinforces the identity of the embryo of the jaipongan dance that was born from the local cultural environment of the people of West Java, the Sundanese people in particular. Apart from the terms of the three aspects above, the concept of 3G, namely gitek, goyang, geol, is one of the local cultural identities applied in the concept of creating the Jaipongan dance. This $3 G$ concept has also become the foundation for the development of movements created by young jaipongan dance creators today.

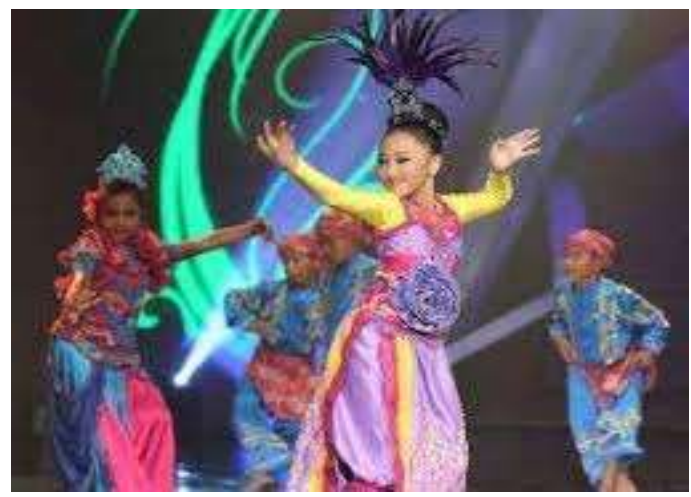

Figure 1. Jaipongan Perforamnce in Television Industry

(Doc. Inahouse2020.wordpress.com)

Local, Pop and Global Cultural Strength in Jaipongan Dance Music

Nowadays, the development of jaipongan dance accompaniment music has made significant progress. This progress is shown by the current jaipongan dance music works that collaborate various sound elements from conventional musical instruments (Sundanese gamelan musical

instruments) with digital musical instruments (sound effects). This condition shows that the creative and innovative process of jaipongan dance music creators has been able to keep up with the progress of science and technology advances in the world of traditional music. Jaipongan dance music works such as in the songs Leungiteun, Sancang Gugat, Gayana, Subali Sugriwa, and Ronggeng Nyetrik have combined traditional music aesthetics in the jaipongan dance with music produced from technology (digital music). The various influences of era development have been responded positively through modern works and have become the identity of the cultural spirit of the era. Another interesting phenomenon from the development of jaipongan dance accompaniment music in industrial packaging and a pop culture framework is the entry of western 
music genres such as rap music or Hip Hop music genres, Accapella music, beatbox music, and digitalbased music. the development of current jaipongan dance music, especially in the process of developing creative and contemporary jaipongan dances.

The combination of traditional jaipong music nuances with genres of pop, rap, beatbox, and digital music, makes the jaipongan dance music currently being developed has a high difficulty level when studied by non-academic or natural artists (selftaught). However, the form of musical presentation developed is still rooted in the traditional values that characterize the art of jaipong. In the process of cultivating a dance and music stylist always communicates both offline and via social media to agree on describing the concept of music to be made and after that there must be face-to-face direct contact for the music. From discussing the concept then to the cultivation process. For the process of cultivating the movements, sometimes a

jaipongan dance stylist is first inspired by the process of stimulating the audio to music that has been made, then the dance is worked out or vice versa. The movements used to be worked on by a dance stylist, after that the accompaniment music was made by a music stylist.

\section{Modern Jaipongan Dance Clothing}

The concept of clothing used in jaipongan dance shows has now undergone a fairly advanced and more modern development. The jaipongan dance fashion designers currently have combined the concept of traditional jaipongan dance clothing with the concept of jaipongan dance clothing which is considered more adaptive to the development of the times. Jaipongan clothing designed by Jugala prioritizes the suitability of the dance content which has the meaning of its use. It is different from today's designers who put aside the contents of the dance and its meaning, but emphasize the current trend. The culture of fashion trends usually inspires a lot of current jaipongan dance fashion designers in designing and making japoingan dance clothes in the present era.

In general, the concept of the current jaipongan dance dress is still based on local wisdom which is manifested in past and present jaipongan dance clothes. The use of apok, kabaya, and sinjang is the basis for the development of jaipongan dance clothes that are currently developing. In this case Jumantri \& Nugraheni, (2020) explained that the dance clothes in Jaipongan are the basic clothes of the Pahumaan community for a woman, namely the kabaya and the sinjang. Historically, the development of jaipongan dance clothing has been influenced by the basis of local cultural wisdom which is manifested in the aesthetics of the jaipongan dance dress. The culture of

wearing kabaya and the use of sinjang for the underside of female dancers' clothing shows a strong bond between the cultural concept developed by the jaipongan dance fashion designer and the culturall background.

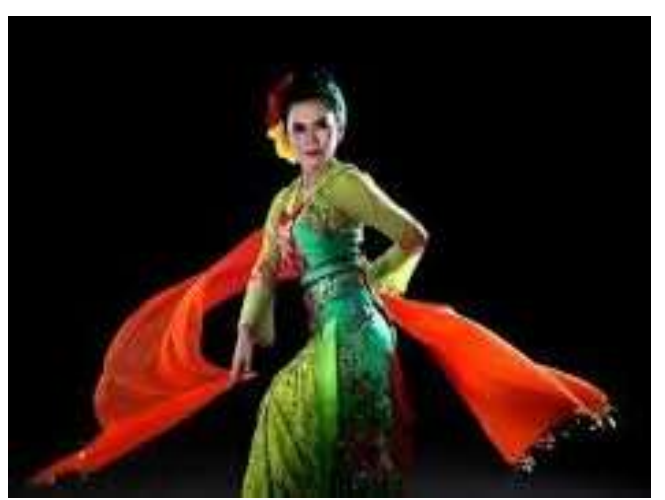

Figure 2. Creative Jaipongan Dance Clothing

(Doc. Kaskus.co.id)

As a whole, according to the spirit of dance, the concept of clothing used by a jaipongan dancer is divided into three main parts, namely the head, to be precise, the use of dance accessories (upper part), the wearing of the dancer's body part (middle part), the hip and leg of the dancer (lower part). In total, the Jaipongan costumes have a suitable character and give a dance identity, namely the Sundanese identity (Mulyadi \& Ramlan, 2012). The Social Influence of Pop Culture in Influencing the Current Packaging of Jaipongan Dance.

Jaipongan dance performance is a form of reflection of the local cultural wisdom values. These values appear in the form and structure in the presentation of the jaipongan dance itself. In other cultural products, a set of local cultures and local wisdom values can be formed in a dance as a result of a relatively long journey that is passed down from one generation to the next through a hereditary process (Pal \& Rahman, 2020) which is often called adiluhung arts. (high cultural arts). The development of the jaipongan dance as a form of counter-culture is widely popularized through the mass media, both print and electronic. In this

position the role of the media is able to provide complete audio and visual or audio-visual information to form a cultural conception of a society related to art forms that are considered popular or in great demand to be published to the public so that they become cultural consumption of 
society. Jaipongan dance as a manifestation of the development of popular culture in Indonesian society can be used by the cultural industry (Lewis, 2002; Slevin, 2000) as a community commodity that is able to bring benefits to its This fact shows that the world of the cultural industry is influenced by the popularity of television, which presents various interesting programs. It turns out that it has been able to spread a cultural virus so that many other forms of art process the colors of jaipongan dance and music as part of the aesthetic exploration of the art performances it displays, such as in dangdut music performances, campur sari and so on. The culture of watching television has become part of the consequences of the influence of global culture that imposes the need for a person or a family to have television as an entertainment medium that has a relatively cheap economic side (Dyer, 2010) capital owners or producers. They only need to sit back at home to watch various television shows from various types of entertainment genres offered by the various television industries, both private and government, which have a quality packaging of high-quality programs and are competitive in capturing the audience (Harrington, 2020 ). Starting from the construction of popular culture television (Wakamatsu, 2011), Jaipongan dance is formed in the text and the context Pop Culture Trends in the Form of Jaipongan Dance Performances.

Discussions about trends in popular culture are always associated with the role of mass media in reconstructing the cultural perceptions of a society that previously had its own cultural identity framework background. Jaipongan from one generation to the next. Because in this case the big role of the mass media which is involved in influencing the way of thinking of jaipongan dance creators in West Java to try to maintai This trend phenomenon will also be related to the commodity of popular culture which is used as a cultural center that is considered more up-to-date and updated. This reality is what jaipongan dance choreographers always want to show from one generation to the next in understanding and adapting the dynamics of changing popular culture trends that the majority of people like. Some examples of Jaipongan dance works are thick with popular cultural influences, such as those created by creative and contemporary jaipongan dance choreographers. Some of the works he created were heavily influenced by the style of modern dance development in the golden era of legendary vocalist Michael Joseph Jackson or known by his short name Michael Jackson.
The influence of the legendary figure of Michael Jackson's music has also influenced the style of creating Jaipongan dance creations known for their robotic motion techniques. One of the works he created is a new creation of jaipongan dance known as breakpong (Breakdance jaipong). In terms of movement techniques, breakdancing is one of the dance genres that developed in the 1970s which was once loved by young people, because the breakdance technique combines elements of gymnastics and acrobatics techniques. Apart from these two dance genres, elements of movement such as robots, kung fu martial arts, and pantomime movements also become colors in the presentation of breakdance. In his golden age, Michael Jackson helped inspire breakers to combine basic breakdancing techniques with the concept of motion techniques popularized by Michael Jackson, who is famous for robotic motion and the moonwalk. Another popular culture trend that has influenced the development of Jaipongan dance creations is the phenomenon of hip hop and ngerep music development trends. Although the movement text is not too dominant, these two elements of hip hop and ngerep music also influence several forms of jaipongan dance presentation such as those developed by contemporary jaipongan dance choregographers. Some of the works he created are the acapella jaipongan dance, beatbox, and mojang priangan. The color of rep and hip hop music appears in the jaipongan dance work above as part of the dance accompaniment music structure which he created to be re-explored into traditional jaipongan dance forms and creations. Although the high level of cultural values (adiluhung) in the jaipongan dance does not seem too strong to be represented by classical traditional dance genres as a manifestation of ideas and ideas of artists from the Menak or Keraton circles. The influence of popular culture can not only be observed from the form of motion and musical accompaniment. Popular culture trends can be observed from the development of jaipongan dance clothing designs made by designers starting from the development of traditional jaipongan up to now. World fashion trends published through various mass media, both print (magazines) or electronic (internet and television) are able to inspire many jaipongan dance designers and fashion makers who always try to adapt to various fashion developments in the world. One example of the influence of popular culture trends that have entered the realm of the design and manufacture of jaipongan dance clothing is the development of modern kabaya clothing 
which was adopted and redesigned in several current jaipongan dance dress concepts. Including a combination of traditional and modern batik materials that are modified in the current jaipongan dance clothes. In the head accessories section, there are also many influences of mass popular culture that are adopted in the concept of current Jaipongan dance clothing. Almost all changes in the development of the presentation of the jaipongan dance as a whole are more influenced by trends in popular culture, one of which is the media of which the mass is more often imitated through television and other types of media (print media) and even through social media (Dow, 2011). Everyone can learn dance or learn dance through television media (Phillips-Fein, 2011), including learning the jaipongan dance.

\section{Discussion}

The development of popular culture in Indonesia and Asia in general is always associated with the issue of the influence of global culture or the era of globalization which has a direct impact on various social, economic and political life arrangements in society (Cohen, 2016, 2018), including the development of the Jaipongan dance performance. currently. It needs to be agreed that the era of globalization is an era of human civilization that directly involves the expansion of cultural products that are born in a societys the buffer that is able to reflect the era of freedom influences the cultural product system it creates. One of the motivations and demands played by traditional artists in their creative processes is the social economy problem (Grierson, 2011). This era does not recognize boundaries between countries with different cultural backgrounds to be open to each other in studying a cultural product of another country so as to produce a cultural product that reflects the spirit of its era (Georgios, 2017). The process of spreading values and norms that are not limited by space and time often has positive and negative consequences on various inter-ethnic cultural communities, including the Indonesian ethnic community which has a pluralistic and the basis of pluralistic multicultural culture. This multicultural form that is brought about by the symptoms of globalization (Liu, 2020), this popular culture is appreciated in the jaipongan dance art products that were born from a process of thinking and The application of thinking within the framework of popular culture is often interpreted by some individuals in a social system as a form of cultural thinking that tries to break away from old or traditional value systems and norms to turn them into something adaptive, dynamic and contemporary. This global phenomenon in local culture is heavily influenced by the spread of culture through technological media, including the development of social media (Jang, 2020), This form of defiance of the old method is able to change the various cultural products it generates into something new and sometimes raises pros and cons against some individuals who obey the system of values and norms that have long been the guiding principles of behavior in society. Popular culture that develops in society has more to adopt the desires of the cultural industry (Chua \& Cho, 2012) and mass communities (Tilsen \& Nylund, 2016), including in the development of Jaipongan dance in Indonesia. This cultural situation shows an indication of the commercialization of popular culture (Markula, 2020) which is used by jaipongan dance actors to meet the demands of industrial culture generation. This reaction can be seen in the development of the current jaipongan dance creations which in form and structure have a new color identity that is different from the standard development of the jaipongan dance in Gugum Gumbira era which became the pioneer to the birth of the jaipongan dance genre in Indonesia. The development of popular culture in dance performances in Indonesia has been heavily influenced by the vibrant dance performances in the television industry (Warburton, 2011). This cultural phenomenon is an indication of the influence of the globalization of popular culture on the way of thinking of current jaipongan dance creators of different generations. This condition also characterizes the consequences of the concept of plurarism in culture, especially the development journey of the Jaipongan dance in Indonesia.

\section{Conclusion}

The jaipongan dance as a local cultural product has a taste of popular culture and global culture created by young creators of creative and contemporary jaipongan dance to balance jaipongan dance connoisseurs today. The innovative and creative thoughts of jaipongan dance creators are manifested in their work by applying an understanding of the order of local cultural values, global culture and popular culture in their creative processes. This phenomenon shows that most of the traditional dances (high arts) that have developed in Indonesia are dynamic and adaptive. This effort was made by the creators of Jaipongan dance to maintain, preserve and develop the work of their predecessors so that 
they are still in demand by the next generation to be studied as an appreciation and process of cultural transformation from one generation to the next so that they are not interrupted by the strong flow of popular culture.

These results indicate that the jaipongan dance is a product of traditional art, but not as a local cultural product that is dead and closes itself to external cultural influences which will actually provide a new ornament as a strengthening of its identity in this era of globalization. The research will provide policy recommendations and evaluations to further increase the productivity of jaipongan dance works that have the tastes of the global cultural community so that they can survive strong in the future from various stimuli from outside cultural influences that will shake the beliefs of jaipongan dance lovers today to switch to popular culture and global which is considered more modern and contemporary. and the global cultural spirit that is embeded in the generation.

\section{Acknowledgemnts}

At the end of this paper, we would like to thank the Universitas Pendidikan Indonesi and Community Service Research Institute for funding this research, so that we can complete this research activity which is manifested in this paper as one of the output products of his research.

\section{References}

1. Appadurai, A. (1990). Disjuncture and difference in the global cultural economy. Theory, Culture \& Society, 7(2-3), 295-310.

2. Aragon, L. V. (2012). The problems of owning culture: global intellectual property law and 'traditional' community arts in Indonesia. Asian Ethnicity, 13(4), 399-417. https://doi.org/10.1080/14631369.2012.7100 77

3. Appadurai, A. (1990). Disjuncture and difference in the global cultural economy. Theory, Culture \& Society, 7(2-3), 295-310.

4. Aragon, L. V. (2012). The problems of owning culture: global intellectual property law and 'traditional' community arts in Indonesia. Asian Ethnicity, 13(4), 399-417. https://doi.org/10.1080/14631369.2012.7100 77

5. Asfina, R., \& Ovilia, R. (2016). Be proud of Indonesian cultural heritage richness and be alert of its preservation efforts in the global world. Humanus: Jurnal Ilmiah Ilmu-Ilmu Humaniora, 15(2), 195-206.

6. Beck, U. (2018). What is globalization? John Wiley \& Sons.

7. Berger, H. M., \& Carroll, M. T. (2003). Global pop, local language. Univ. Press of Mississippi.

8. Chua, B. H., \& Cho, Y. (2012). Editorial introduction: American pop culture. InterAsia Cultural Studies, 13(4), 485-494. https://doi.org/10.1080/14649373.2012.7175 96

9. Cohen, M. I. (2016). Global Modernities and Post-Traditional Shadow Puppetry in Contemporary Southeast Asia. Third Text, 30(3-4), 188-206. https://doi.org/10.1080/09528822.2017.1305 728

10. Cohen, M. I. (2018). The dr. walter angst and sir henry angest collection of indonesian puppets: The structure of the conjuncture. Asian Theatre Journal, 35(2), 300-328.

11. Crothers, L. (2017). Globalization and American popular culture. Rowman \& Littlefield.

12. Danesi, M. (2008). Popular culture. The Year's Work in Critical and Cultural Theory.

13. De Duve, T. (2007). The glocal and the singuniversal: Reflections on art and culture in the global world. Third Text, 21(6), 681688.

14. Dimitrakaki, A. (2012). Art, globalisation and the exhibition form: What is the case, what is the challenge? Third Text, 26(3), 305-319.

15. Dow, C. B. (2011). Dance, Pop Culture and Community: A Tale of Two Flash Mobs. Journal of Dance Education, 11(4), 140-142. https://doi.org/10.1080/15290824.2011.6168 18

16. Dyer, C. E. (2010). Reality television: Using para-social relationship theory and economic theory to define the success of network reality programming. University of North Texas.

17. Edgar, A., \& Sedgwick, P. (2007). Cultural theory: The key concepts. Routledge.

18. Eriksen, T. H. (2002). Ethnicity and nationalism: Anthropological perspectives. Pluto press.

19. Featherstone, M. (1990). Global culture: Nationalism, globalization and modernity (Vol. 2). Sage. 
20. Foley, C. (2001). Perceptions of Irish step dance: national, global, and local. Dance Research Journal, 33(1), 34-45.

21. Friedman, J. (1994). Cultural identity and global process (Vol. 31). Sage.

22. Georgios, L. (2017). The Transformation of Traditional Dance from Its First to Its Second Existence: The Effectiveness of Music Movement Education and Creative Dance in the Preservation of Our Cultural Heritage. Journal of Education and Training Studies, 6(1),

104. https://doi.org/10.11114/jets.v6i1.2879

23. Grierson, E. (2011). Art and Creativity in the Global Economies of Education. Educational Philosophy and Theory, 43(4), 336-350. https://doi.org/10.1111/j.1469-

5812.2009.00550.x

24. Harrington, H. (2020). Consumer dance identity: the intersection between competition dance, televised dance

25. shows and social media. Research in Dance Education, 21(2), 169-187. https://doi.org/10.1080/14647893.2020.1798 394

26. Hatley, B. (2008). Javanese Performances on an Indonesian Stage: Celebrating Culture, Embracing Change. NUS Press.

27. Jang, K. (2020). Creating the sacred places of pop culture in the age of mobility: fan pilgrimages and authenticity through performance. Journal of Tourism and Cultural Change, 18(1), 42-57. https://doi.org/10.1080/14766825.2020.1707 463

28. Jenner, M. (2018). Introduction: Control, Power, Television. In Netflix and the Reinvention of Television (pp. 35-45). Springer.

29. Johnson, H. (2002). Balinese music, tourism and globalisation: Inventing traditions within and across cultures. New Zealand Journal of Asian Studies, 4(2), 8-32.

30. Jumantri, M. C., \& Nugraheni, T. (2020). Pengkajian Gaya Busana Tari Jaipongan Karya Sang Maestro The Study of Jaipongan Dance Costume by The Maestro. Gondang, 4(1), 9-15.

31. Jung, S. (2011). K-pop, Indonesian fandom, and social media| Jung| Transformative Works and Cultures. Transformative Works \& Cultures, 8 .

32. Khondker, H. H. (2004). Glocalization as globalization: Evolution of a sociological concept. Bangladesh E-Journal of Sociology, 1(2), 1-9.

33. Kolb, A. (2013). The migration and globalization of schuhplattler dance: A sociological analysis. Cultural Sociology, 7(1), 39-55.

34. Lewis, J. (2002). Cultural studies-the basics. Sage.

35. Liu, S. (2020). The Chinese dance: a mirror of cultural representations. Research in Dance Education, 00(00), 1-16. https://doi.org/10.1080/14647893.2020.1782 371

36. Livholts, M., \& Bryant, L. (2017). Social work in a glocalised world. Taylor \& Francis.

37. Lopes, R. O. (2014). Meeting another China: exhibiting Chinese [folk] art and popular culture in the Orient Museum. World Art, 4(2), 237-261. https://doi.org/10.1080/21500894.2014.9375 05

38. Markula, P. (2020). Dance, movement and leisure cultures. Leisure Studies, 39(4), 465478.

https://doi.org/10.1080/02614367.2020.1731 843

39. Martell, L. (2016). The sociology of globalization. John Wiley \& Sons.

40. Mirjana Veselinović-Hofman (ed.). (2014). Ethnochoreological Work of Olivera Mladenović. (2), 2013.

41. Mulyadi, E., \& Ramlan, L. (2012). Keser bojong: Idealisasi Pencitraan Jaipongan Karya Gugum Gumbira. Panggung, 22(1), $37-51$.

https://doi.org/10.26742/panggung.v22i1.34

42. Murphy, S. C. (2011). How television invented new media. Rutgers University Press.

43. Narawati, T. (2013). Etnokoreologi : Pengkajian Tari Etnis \& Kegunaannya Dalam Pendidikan Seni. Isla-2, 70-74.

44. Nuriawati., R., \& Nalan., A. S. (2018). Kreativitas Gondo dalam tari jaipongan. Jurnal Ilmiah Seni Pertunjukan Tari Makalangan, 05(02), 27-40.

45. Oliver, W. (2011). The Influence of Pop Culture and Mass Media on Dance Education Today. Journal of Dance Education, 11(4), 111-112. 
Trianti Nugraheni et./al Jaipong Dance: Representation of Local Culture, Popular Culture and Global Culture

https://doi.org/10.1080/15290824.2011.6205 36

46. Pal, B., \& Rahman, M. (2020). Acculturation, cultural resistance, or cultural rigging: A study of folk performances in popular films. South Asian Popular Culture, OO(00), $1-9$. https://doi.org/10.1080/14746689.2020.1816 256

47. Pattie, D. (2013). 16 Popular Culture. The Year's Work in Critical and Cultural Theory, 21(1), 308-327.

48. Phillips-Fein, J. M. (2011). How We Dance: Helping Students Unpack the Impact of Dance Television Shows. Journal of Dance Education, 11(4), 134-136. https://doi.org/10.1080/15290824.2011.6209 37

49. Pieterse, J. N. (1995). Globalization as hybridization. Media and Cultural Studies, 658.

50. Pieterse, J. N. (2004). Globalization or empire? Routledge.

51. Pieterse, J. N. (2019). Globalization and culture: Global mélange. Rowman \& Littlefield.

52. Rehbein, B. (2007). Globalization, culture and society in Laos (Vol. 10). Routledge.

53. Robertson, R. (1992). Globalization: Social theory and global culture (Vol. 16). Sage.

54. Robertson, R. (1995). Glocalization: Timespace and homogeneity-heterogeneity. Global Modernities, 2(1), 25-44.

55. Roudometof, V. (2015). Mapping the glocal turn: Literature streams, scholarship clusters and debates. GLOCALISM: Journal of Culture, Politics and Innovation, 3, 1-21.

56. Roudometof, V. (2016). Theorizing glocalization: Three interpretations1. European Journal of Social Theory, 19(3), 391-408.

57. Roudometof, V. (2019). Recovering the local: From glocalization to localization. Current Sociology, 67(6), 801-817.

58. Sandikci, Ö., \& Ger, G. (2002). In-between modernities and postmodernities: theorizing Turkish consumptionscape. Advances in Consumer Research, 29(1), 465-470.

59. Scholte, J. A. (2005). Globalization: A critical introduction. Macmillan International Higher Education.

60. Shuker, R. (2016). Understanding popular music culture. Routledge.
61. Slevin, J. (2000). Internet and society. Blackwell Publishers, Inc.

62. Smith, A. D., \& Smith, A. (2013). Nationalism and modernism. Routledge.

63. Smith, M. (2007). Glocalization. The Blackwell Encyclopedia of Sociology.

64. Steenkamp, J.-B. (2017). Global brand strategy: World-wise marketing in the age of branding. Springer.

65. Steenkamp, J.-B. E. M., \& de Jong, M. G. (2010). A Global Investigation into the Constellation of Consumer Attitudes toward Global and Local Products. Journal of Marketing, $\quad 74(6), \quad 18-40$. https://doi.org/10.1509/jmkg.74.6.18

66. Stokes, J. (2012). How to do media and cultural studies. Sage.

67. Storey, J. (2006). Cultural theory and popular culture: A reader. University of Georgia Press.

68. Tilsen, J., \& Nylund, D. (2016). Cultural studies methodologies and narrative family therapy: Therapeutic conversations about pop culture. Family Process, 55(2), 225-237.

69. Van Dijck, J., \& Poell, T. (2015). Making public television social? Public service broadcasting and the challenges of social media. Television \& New Media, 16(2), 148164.

70. Wakamatsu, K. A. (2011). From Pop Culture to Sophisticated Art: Helping K-12 Students Bridge the Gap. Journal of Dance Education, 11(4),

129-133. https://doi.org/10.1080/15290824.2011.6205 35

71. Warburton, E. C. (2011). Staying Alive: On Popular Culture, Dance Education and Generation Why. Journal of Dance Education, 11(4), 113-118. https://doi.org/10.1080/15290824.2011.6169 41

72. Zolberg, V. L. (2015). A cultural sociology of the arts. Current Sociology, 63(6), 896915. 